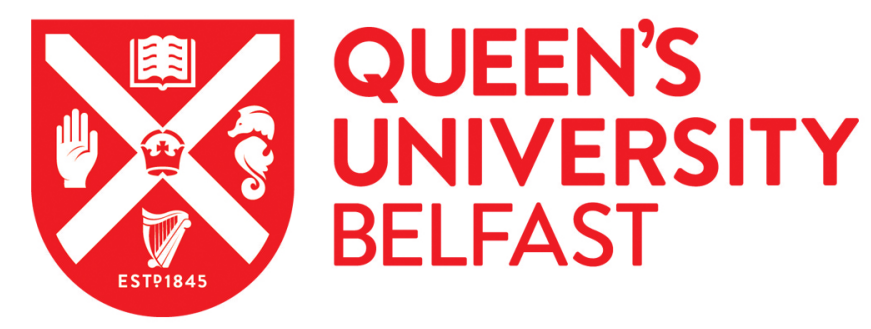

\title{
Diversity of arbuscular mycorrhizal fungi associated with desert ephemerals growing under and beyond the canopies of Tamarisk shrubs
}

Shi, Z. Y., Zhang, L. Y., Feng, G., Christie, P., Tian, C. Y., \& Li, X. L. (2006). Diversity of arbuscular mycorrhizal fungi associated with desert ephemerals growing under and beyond the canopies of Tamarisk shrubs. Chinese Science Bulletin, 51 (Suppl. 1)(SUPPL. 1), 132-139. https://doi.org/10.1007/s11434-006-8217-9

Published in:

Chinese Science Bulletin

Queen's University Belfast - Research Portal:

Link to publication record in Queen's University Belfast Research Portal

\section{General rights}

Copyright for the publications made accessible via the Queen's University Belfast Research Portal is retained by the author(s) and / or other copyright owners and it is a condition of accessing these publications that users recognise and abide by the legal requirements associated with these rights.

Take down policy

The Research Portal is Queen's institutional repository that provides access to Queen's research output. Every effort has been made to ensure that content in the Research Portal does not infringe any person's rights, or applicable UK laws. If you discover content in the Research Portal that you believe breaches copyright or violates any law, please contact openaccess@qub.ac.uk. 
Chinese Science Bulletin 2006 Vol. 51 Supp. I 132-139

DOI: $10.1007 / \mathrm{s} 11434-006-8217-9$

\section{Diversity of arbuscular} mycorrhizal fungi associated with desert ephemerals growing under and beyond the canopies of Tamarisk shrubs

\author{
SHI Zhaoyong ${ }^{1,2}$, ZHANG Liyun $^{1}$, FENG Gu$^{2}$, \\ Christie Peter ${ }^{2,3}$, TIAN Changyan ${ }^{1}$ \& LI Xiaolin ${ }^{2}$
}

1. Xinjiang Institute of Ecology and Geography, Chinese Academy of Sciences, Urumqi 830011, China;

2. College of Resources and Environmental Sciences, China Agricultural University, Beijing 100094, China;

3. Agricultural and Environmental Science Department, Queen's University Belfast, Belfast BT9 PX, UK

Correspondence should be addressed to Feng Gu (email: fenggu@ cau.edu.cn)

Received July 20, 2005; accepted January 16, 2006

Abstract The arbuscular mycorrhizal (AM) fungal status of the four most common ephemeral plant species, Chorispora tenella (Pall.) DC., Ceratocephalus testiculatus (Crantz) Bess., Eremopyrum orientale (L.) Jaub et. Spash and Veronica campylopoda Boiss growing in an area dominated by Tamarisk shrubs (Tamarix spp.) was investigated. Samples of the four ephemerals and their rhizosphere soils were collected from underneath and beyond the canopies of the Tamarisk shrubs. Plant mycorrhizal status and soil AM fungal spore densities and community structures were analyzed and compared under and beyond the shrub canopies. The mycorrhizal colonization rates of the ephemerals and spore densities in their corresponding rhizosphere soils were significantly lower under the shrub canopies than beyond. The number of AM fungal species under the shrubs (12) was also lower than beyond the canopies (19). When soil properties in the rhizospheres of the four ephemerals were examined, available $\mathrm{N}$ and $\mathrm{P}$ and total $\mathrm{P}$, organic matter content, total salt content and electrical conductivity $(E C)$ were all higher under the canopies than beyond. In contrast, soil available $\mathrm{K}$ and $\mathrm{pH}$ showed no such trend. A total of 21 AM fungal species were isolated from rhizosphere soils of the four ephemerals. Five belonged to Acaulospora, one to Archaeospora, thirteen to Glomus and two to Paraglomus. We conclude that the canopies of Tamarix spp. exerted some influence on the AM status of the ephemerals and on the AM fungal communities and some of the properties of their rhizosphere soils.

Keywords: arbuscular mycorrhizal fungi, ephemeral plant species, Tamarix spp. canopy, mycorrhizal colonization rate, spore densities.

Shrubs in arid ecosystems typically grow in patchy distributions with low plant cover and the vegetation patches commonly constitute 'fertility islands ${ }^{[1]}$, or 'resource islands ${ }^{,[2,3]}$, where facilitation among plants may be strongly fostered ${ }^{[4,5]}$. Fertility islands may differ from areas outside plant canopies (interspatial soils) in numerous ways including the occurrence of high concentrations of soil nitrogen and other nutrients ${ }^{[6]}$, reduced solar radiation and lower soil temperatures ${ }^{[7-10]}$. He et al. (2002) ${ }^{[11]}$ showed that shrubs influenced AM fungal diversity. Arbuscular mycorrhizal (AM) fungi are soil microorganisms known to establish a universally distributed mutualistic association with the majority of higher plant species. Arbuscular mycorrhizas are widespread among terrestrial plants, with mycorrhizas occurring in $83 \%$ of the dicotyledonous and $79 \%$ of the monocotyledonous species observed so $\operatorname{far}^{[12,13]}$. It is well known that AM fungi promote plant establishment by increasing resistance to environmental stresses, increasing plant nutrient acquisition and enhancing soil quality. As a result, AM fungi can increase plant diversity and productivity and succession in plant communities $^{[14,15]}$. There is considerable evidence that mycorrhizal associations play a significant role in the stability and productivity of natural ecosystems. Because of the key ecological functions of AM associations, loss or diminution of mycorrhizal potential in degraded areas may limit the successful reestablishment of the native plants ${ }^{[16,17]}$. Investigations of AM fungal diversity may therefore help us to understand the developmental trends and productivity of plant communities.

There have been several studies on arbuscular mycorrhizal fungi in the fertility islands of shrubs ${ }^{[18-22]}$. However, most studies have concentrated on the arbuscular mycorrhizal status of the shrubs themselves and the AM fungal diversity in their rhizosphere soils. We hypothesize that shrubs can influence the arbuscular mycorrhizas of neighbouring herbaceous plant species growing under their canopies and AM fungal diversity in their rhizosphere soils. In the present study we selected four ephemeral plant species growing under and beyond the canopies of Tamarix spp. Ephemer- 


\section{ARTICLES}

als are specially adapted desert plants that remain dormant until rare rainfall events occur. They then spring to life and grow and flower quickly before the desert dries up again. It is a particular trait of desert plants in variable areas that they can take advantage of water resources and temperature conditions in the spring to complete their life cycle in only about two months ${ }^{[23,24]}$. Ephemerals include two types of plants, annuals that develop from seed and perennials with a very short epigeous period during which shoots are present aboveground that germinate from corms or seeds each year ${ }^{[25]}$. As an important and unique component of China's desert flora, ephemerals can form significant synusia from late March to mid June, a season witnessing the strongest wind forces in the desert regions of north Xinjiang Autonomous Region. They are also one of the zonal indicators of botanic geography in the arid zone of Eurasia. Furthermore, ephemerals can stabilize sand dunes and are pioneer species during the rehabilitation of degraded desert areas ${ }^{[26]}$ and they can lower the frequency of occurrence and intensity of sandstorms. In addition, ephemerals are a valuable resource providing flowers, grazing and medicinal materials in early spring in desert ecosystems. Accordingly, these plants have attracted the interest of ecologists and botanists ${ }^{[25,27-30]}$. However, to our knowledge there have been no studies on AM associations of ephemeral plants. The objectives of the present survey were to investigate and compare the AM fungal colonization and developmental status of ephemerals and AM fungal communities in the rhizosphere soils under and beyond the canopies of Tamarisk shrubs, to understand the characteristics of 'fertility islands' and to explain the process of desertification.

\section{Materials and methods}

\subsection{Study sites}

The study was carried out at the Tamarisk shrublands $\left(44^{\circ} 7.487^{\prime} \mathrm{N}, 87^{\circ} 49.099^{\prime} \mathrm{E}\right)$ located $50 \mathrm{~km}$ from Urumqi in the southern Junggar Basin of the northern Tianshan Mountains, northern Xinjiang Autonomous Region, northwestern China. The area lies in the climatic zone of continental aridity, with an annual mean temperature of $5.7^{\circ} \mathrm{C}$, hot and dry summers (highest monthly mean temperature $23.5^{\circ} \mathrm{C}$ in July), and cold winters (lowest monthly mean temperature $-15.4^{\circ} \mathrm{C}$ in January). The annual average precipitation is about $200 \mathrm{~mm}$ and the annual latent evaporation is about $2500 \mathrm{~mm}$. However, about $45 \%$ of the precipitation occurs during spring. The average altitude is $518 \mathrm{~m}$ above sea level. The soil type is aridisol according to the USDA soil classification system. Over ten species of Tamarix occur naturally over the area and form a dominant component of the plant cover. They are very difficult to identify to species level and their distribution is closely related to soil moisture conditions. Among the associated herbaceous plant species, ephemerals develop in spring before the Tamarisk shrubs sprout and they are the dominant plant species. In particular, Chorispora tenella (Pall.) DC., Ceratocephalus testiculatus (Crantz) Bess., Eremopyrum orientale (L.) Jaub et. Spash and Veronica campylopoda Boiss are the most common species both under and beyond the Tamarisk canopies. Other plant species present include other ephemerals such as Lepidium perfoliatum (Cruciferae), Tulipa illiensis (Liliaceae) and the annual or perennial species Phragmites australis subsp. Australis (Gramineae), Aeluropus sp. (Gramineae), Suaeda acuminate (Chenopodiaceae), Halostachys caspica (Chenopodiaceae), and Camphorosma monspeliaca (Chenopodiaceae). When the plant species associated with the Tamarisk shrubs were examined no differences in plant species richness or density were observed under the shrub canopies compared with plants beyond the canopies.

\subsection{Collection of soil and root samples}

The four commonest ephemerals, Chorispora tenella (Pall.) DC., Ceratocephalus testiculatus (Crantz) Bess., Eremopyrum orientale (L.) Jaub et. Spash and Veronica campylopoda Boiss were surveyed. Samples of roots and soils were collected from the rhizospheres of four plants of the same species randomly distributed under and beyond Tamarisk shrub canopies during April and May 2004 according to the procedures described by Liu and $\mathrm{Li}^{[31]}$. Ten shrub canopies and locations between canopies were investigated. Care was taken during the collection of individual plants that the roots could be positively identified as belonging to a particular individual plant. The root samples of the ephemerals were dug out together with plants to ensure that the roots were connected to those particular plants. Samples were taken to the laboratory for determination of AM root colonization. The soil samples had a sandy texture and were then air-dried in the shade at ambient laboratory temperature for spore extraction, counting and identification. Soil physicochemical properties were measured according to the methods described by $\mathrm{Lu}^{[32]}$. 


\section{ARTICLES}

\subsection{Measurement of AM colonization}

Fine and fibrous roots were selected to obtain subsamples of the fresh root samples. After thorough washing to remove all soil particules, roots were placed in plastic cassettes used in medicine for processing biopsy tissues. The roots were cleared with $10 \%(\mathrm{w} / \mathrm{v})$ $\mathrm{KOH}$ by heating to $90^{\circ} \mathrm{C}$ in a water bath for $20-30$ min, the exact time depending on the degree of lignification of the roots and their pigmentation. The cooled root samples were washed 4-5 times with water, cut into 0.5 - to $1.0-\mathrm{cm}$-long segments, and immersed in $2 \%$ (v/v) $\mathrm{HCl}$ for $15-20 \mathrm{~min}$ and stained with $0.05 \%(\mathrm{w} / \mathrm{v})$ acid fuchsin ${ }^{[33]}$. To determine the proportion of root length colonized by AM fungi, thirty cleared and stained root segments were mounted on slides (10 per slide) and the colonized root tissue was evaluated according to the method of Trouvelot et al. ${ }^{[34]}$. The AM fungal structures present were also recorded.

\subsection{Enumeration and isolation of AM fungal spores}

AM fungal spores were isolated from $20-\mathrm{mL}$ subsamples of air-dried soil by the wet sieving and decanting method followed by sucrose centrifugation ${ }^{[35]}$. After centrifugation, each supernatant was poured through a $50-\mu \mathrm{m}$ mesh and quickly rinsed with tap water. Turgid spores (suggesting viability) were grouped under a dissecting microscope at $40 \times$ magnification according to their morphological characteristics. All spores that were intact, i.e. non-collapsed, with cytoplasmic contents and free from parasitic attack, were counted. Sporocarps and spore clusters were considered as one unit. Diagnostic permanent slides were prepared for each different spore morphotype using either polyvinyl-lactoglycerol (PVLG) or PVLG+Melzer's $(1: 1)$ reagent. After confirming the uniformity of the morphological groups under the optical microscope, the different morphotypes were identified to genus and species. Spore identification was based mainly on spore size, colour, wall structure and hyphal attachment ${ }^{[36]}$. Spore identification was corroborated by comparison with the descriptions of the reference cultures in INVAM (http://invam.cag.wvu.edu) and IBG (International Bank of the Glomales). AM fungal spores were classified according to the taxonomic system devised by Morton and Redecker ${ }^{[37]}$.

\subsection{Statistical analysis}

One-way analysis of variance (ANOVA) was used to compare AM fungal colonization and spore density in the rhizosphere of the four ephemerals under the Tamarisk canopies with those beyond. The SPSS software package version 11.0 was used.

\section{Results}

\subsection{Soil properties}

Soil properties under the canopies were: total salt content $1.57 \mathrm{~g} / \mathrm{kg}, \mathrm{pH} 8.24$, organic matter content 16.5 $\mathrm{g} / \mathrm{kg}$, available $\mathrm{N} 65.4 \mathrm{mg} / \mathrm{kg}$, available $\mathrm{P} 44.5 \mathrm{mg} / \mathrm{kg}$, available $\mathrm{K} 217 \mathrm{mg} / \mathrm{kg}$, total $\mathrm{P} 0.64 \mathrm{~g} / \mathrm{kg}$, and electrical conductivity $0.40 \mathrm{mS} / \mathrm{cm}$. Values beyond the canopies were: total salt content $0.81 \mathrm{~g} / \mathrm{kg}, \mathrm{pH} 8.38$, organic matter content $14.5 \mathrm{~g} / \mathrm{kg}$, available $\mathrm{N} 32.3 \mathrm{mg} / \mathrm{kg}$, available P $33.85 \mathrm{mg} / \mathrm{kg}$, available K $344 \mathrm{mg} / \mathrm{kg}$, total $\mathrm{P} 0.63 \mathrm{~g} / \mathrm{kg}$, and electrical conductivity $0.18 \mathrm{mS} / \mathrm{cm}$. All soil parameters except for $\mathrm{pH}$ and available $\mathrm{K}$ had higher values under the canopies than beyond.

\subsection{Comparison of AM fungal colonization status}

The AM fungal colonization status of the four ephemerals under and beyond the shrub canopies is shown in Fig. 1. No AM fungal colonization was observed in roots of Chorispora tenella (Pall.) DC. either under the shrub canopies or beyond. The other three species were colonized by AM fungi, with the proportion of root length colonized ranging from $0.9 \%$ to $18.8 \%$. The extent of root colonization on all three mycorrhizal ephemerals was affected significantly by the shrub canopies, with higher colonization under the canopies than beyond $(p<0.01)$. Ceratocephalus testiculatus showed the highest colonization rates both under $(7.3 \%)$ and $(18.0 \%)$ shrub canopies.

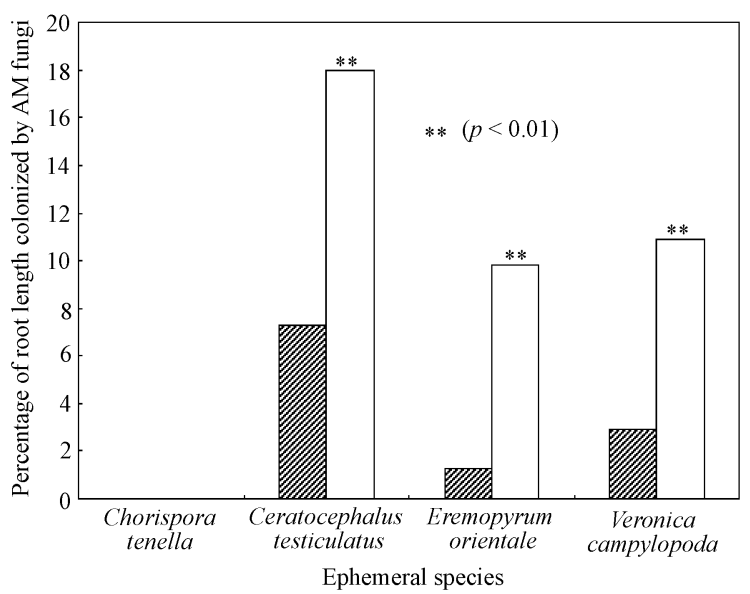

Fig. 1. Mean arbuscular mycorrhizal colonization rate of ephemerals under (hatched bars) and beyond (open bars) the Tamarisk canopies. 


\section{ARTICLES}

\subsection{AM structures under and beyond Tamarisk cano- pies}

AM structures of ephemerals collected under and beyond shrub canopies are shown in Table 1. No AM structures were observed in Chorispora tenella either under or beyond the shrub canopies. Vesicles, intra-radical non-septate hyphae and extra radical non-septate hyphae were observed in root samples of Ceratocephalus testiculatus, Eremopyrum orientale and Veronica campylopoda. Arbuscules were observed in two out of the four plant species growing beyond the canopies. No arbucules were found in any root samples collected from under the shrub canopies.

\subsection{AM fungal spore densities}

The spore densities in $20 \mathrm{~mL}$ rhizosphere soil of four ephemeral species growing under and beyond the shrub canopies are presented in Fig. 2. The spore densities under the canopies were significantly lower than those beyond. The sequence of the four ephemerals in terms of AM spore density differed under and beyond the canopies as follows: Eremopyrum orientale (31), Ve-

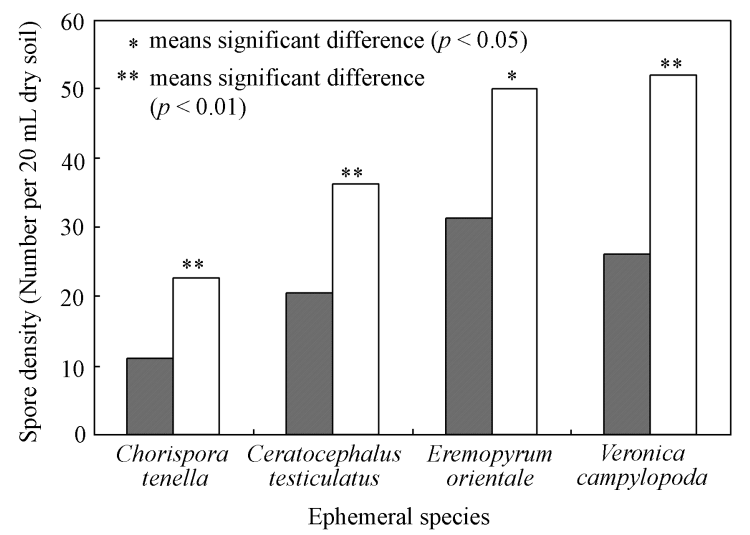

Fig. 2. Mean AM fungal spore densities in rhizospheres of ephemerals under (hatched bars) and beyond (open bars) the Tamarisk canopies. ronica campylopoda (26), Ceratocephalus testiculatus (21), and Chorispora tenella (11) under the canopies, and Veronica campylopoda (52), Eremopyrum orientale (50), Ceratocephalus testiculatus (36), and Chorispora tenella (23) beyond the canopies.

\subsection{AM fungal species identified}

Twenty-one AM fungal species belonging to four genera, with one species in Archaeospora, five in Acaulospora, thirteen in Glomus and two in Paraglomus, were isolated and identified in the rhizosphere of the four ephemeral species under and beyond the shrub canopies (Table 2). Twelve species representing 3 genera of AM fungi were present in the rhizospheres of the ephemerals growing under the shrub canopies. Among the 12 species, 2 belonged to Acaulospora, 8 to Glomus and 2 to Paraglomus, with no Archaeospora spp. present. Except for G. mosseae and P. occltum, all AM fungal species were isolated and identified in the rhizospheres of ephemerals beyond the shrub canopies. All four ephemeral species showed higher numbers of AM fungal species in the rhizosphere soil beyond the shrub canopies than under the canopies.

\section{Discussion}

Studies on the interactions among plants, microorganisms and the environment are necessary prerequisites for understanding the course of desertification $^{[38-40]}$. Numerous studies have shown that AM fungi can enhance the $\mathrm{P}$ nutrition of host plants, increase the diversity and stability of plant communities, and enhance the resistance of host plants to abiotic stresses such as drought and salt stress ${ }^{[16,41-43]}$. Until now, few studies have been carried out on the mycorrhizal status of ephemeral plants that play an important role in the stability of desert ecosystems. In the

Table 1 Typical arbuscular mycorrhizal structures in ephemerals under and beyond the Tamarisk canopies

\begin{tabular}{|c|c|c|c|c|}
\hline Host plant species & Arbuscules ${ }^{\text {b) }}$ & Vesicles & Intra-radical non-septate hyphae & Extra-radical non-septate hyphae \\
\hline Chorispora tenella (Pall.) DC. a) & - & - & - & - \\
\hline Chorispora tenella (Pall.) DC. & - & - & - & - \\
\hline Ceratocephalus testiculatus (Crantz) Bess. ${ }^{\text {a) }}$ & - & + & ++ & + \\
\hline Ceratocephalus testiculatus (Crantz) Bess. & + & ++ & ++ & ++ \\
\hline Eremopyrum orientale (L) Jaub et Spash ${ }^{\text {a) }}$ & - & $(+)$ & + & + \\
\hline Eremopyrum orientale (L) Jaub et Spash & - & + & ++ & + \\
\hline Veronica campylopoda Boiss. ${ }^{\text {a) }}$ & - & + & + & + \\
\hline Veronica campylopoda Boiss. & + & + & ++ & ++ \\
\hline
\end{tabular}

a) Samples were collected under canopies of Tamarix ramosissima Lebedour. b) ++ , always present in significant numbers; + , always present; $(+)$, very rare, only present in cortical colonization; -, not detected. 
Table 2 AM fungal communities in the rhizosphere soils of ephemerals growing under and beyond Tamarisk canopies

\begin{tabular}{|c|c|c|c|c|c|c|c|c|}
\hline Ephemeral species & Chorispora tenella) $^{\text {a) }}$ & C. tenella & $\begin{array}{c}\text { Ceratocephalus } \\
\text { testiculatus }^{\text {a) }}\end{array}$ & C. testiculatus & $\begin{array}{c}\text { Eremopyrum } \\
\text { orientale }^{\text {a) }}\end{array}$ & E. orientale & $\begin{array}{c}\text { Veronica } \\
\text { campylopoda }^{\text {a) }}\end{array}$ & $\begin{array}{l}\text { V. campylo- } \\
\text { poda }\end{array}$ \\
\hline \multicolumn{9}{|l|}{ Acaulospora } \\
\hline A. appendicula Spain, Sieverding \& Schenck & & & & $++^{\mathrm{b})}$ & & & + & \\
\hline A. elegans Trappe \& Gerdemann & & & & & & + & & + \\
\hline A. excavate Ingleby \& Walker & + & + & & & + & + & & + \\
\hline A. mellea Spain \& Schenck & & & & & & + & & \\
\hline A. rehmii Sieverding \& Toro & & & & + & & & + & \\
\hline \multicolumn{9}{|l|}{ Archaeospora } \\
\hline Ar. leptoticha (Schenck \& Smith) Morton et R. & & & & & & + & & \\
\hline \multicolumn{9}{|l|}{ Glomus } \\
\hline G. aggregatum Schenck \& Smith emend. Koske & & & + & + & + & + & & \\
\hline G. australe (Berk.) Berch & + & & + & + & & & & \\
\hline G. claroideum Schenck \& Smith & & + & + & + & + & + & + & + \\
\hline G. clarum Nicolson \& Schenk & + & + & & + & & & + & \\
\hline G. deserticola Trappe, Bloss \& Menge & & & + & & + & & & + \\
\hline G. etunicatum Becker \& Gerd. & & & + & + & & + & + & \\
\hline G. geosporum (Nicol. \& Gerd.) Walker & + & + & + & & & + & & + \\
\hline G. globiferum Koske \& Walker & & & & & & & + & \\
\hline G. macrocarpum Gerd. \& Trappe & + & + & + & + & & & + & + \\
\hline G. microcarpum Tul. \& Tul. & & + & & & & & + & \\
\hline G. mosseae (Nicol. \& Gerd.) Gerd. \& Trappe & & & + & & & & & \\
\hline G. multicaule Gerdemann \& Bakshi & & & & & & & & + \\
\hline G. reticulatum Bhattacharjee \& Mukerji & & & & + & & & & + \\
\hline \multicolumn{9}{|l|}{ Paraglomus } \\
\hline P. brasilianum (Spain et Miranda) Morton et. Redecker & + & + & & & & & & + \\
\hline P. occultum (Walker) Morton et. Redecker & & & & & + & & & \\
\hline
\end{tabular}

a) Samples were collected under Tamarisk canopies; b) +, AM fungi were present in samples. 


\section{ARTICLES}

present study, 21 AM fungal species belonging to 4 genera were isolated from the rhizospheres of 4 common ephemerals growing under and beyond Tamarisk shrub canopies and demonstrated that AM fungi were a notable component of the Tamarisk desert ecosystem.

van der Heijden ${ }^{[16]}$ showed that mycorrhizal fungal diversity determines plant biodiversity and ecosystem variability and productivity. AM fungi colonize root tissues biotrophically and form an extensive network of extra-radical mycelium, providing a direct physical link between the soil and plant roots ${ }^{[44]}$. The arbuscular mycorrhizal (AM) fungal status of the four most common ephemerals, Chorispora tenella (Pall.) DC., Ceratocephalus testiculatus (Crantz) Bess., Eremopyrum orientale (L.) Jaub et. Spash and Veronica campylopoda Boiss growing in Tamarisk shrublands were investigated. Their mycorrhizal status, AMF spore densities and community structures were analyzed, and the differences under and beyond the shrub canopies were compared. All four ephemeral species formed AM associations except for Chorispora tenella. The shrub canopies decreased the AM colonization rate of ephemerals and the AM fungal diversity in the rhizosphere soils of three mycorrhizal ephemeral species. The root colonization rate and occurrence of AM fungal structures were lower under the canopies than beyond. Possible explanations are higher nutrients restraining colonization and spore reproduction under the canopies because AM fungal infection levels are generally inversely correlated with nutrient availability (especially phosphorus and nitrogen) and soil moisture ${ }^{[45,46]}$. In addition, He et al. ${ }^{[47]}$ showed that AM fungal spore densities were negatively correlated with soil available $\mathrm{N}$ under halophyte canopies in the Negev Desert. In our study site all soil nutrition concentrations measured were higher under the canopies than beyond, except for available K. The relatively high soil nutrient concentrations under the canopies may have led to a decrease in the mycorrhizal dependence of the ephemerals compared with those growing beyond the canopies. This result supports the conclusion of Dhillion and $\mathrm{Zak}^{[48]}$ that when plants have high nutrient availability, a negative response of AM fungi and low infection levels may be expected. Another possible explanation is that the higher water and nutrient contents increased root development under the canopies, resulting in lower mycorrhizal colonization rates under the canopies than beyond.

Although AM structures were not observed in the ephemeral species Chorispora tenella, AM fungal spores were isolated from its rhizosphere soils. This may be due to the intermingling of plant roots of different species in the field sample so that mycorrhizal plants may have influenced sporulation in the rhizosphere soils of non-mycorrhizal plants.

Twenty-one AM fungal species were isolated from the rhizosphere soils of the ephemerals and identified. The number of AM fungal species extracted was higher than in some previous investigations in desert ecosystems. For example, 15 AM fungal species associated with Sporobolus wrightii were found in riparian habitats in arid south-western North America ${ }^{[49]}$. Far fewer AM fungi (5 species) were isolated in shrub-associated resource islands from a semiarid Mediterranean ecosystem threatened by desertification ${ }^{[22]}$. It is unlikely that the desertification was serious in our sampling sites because the soil total salt content was relatively low $(1.57 \mathrm{~g} / \mathrm{kg})$. Other possible explanations are differences in ecological factors or species of shrub, and further studies are required to elucidate these factors in detail. In addition, we still do not understand how AM fungi associated with ephemerals complete their life cycle after the death of the ephemeral host plants and this question requires intensive study.

The spore densities of AM fungi in rhizosphere soils of ephemerals were relatively high (mean of 31 per 20 $\mathrm{mL}$ air-dried soil). Kennedy and Smith ${ }^{[50]}$ showed that land degradation tended to reduce microbial diversity and/or activity belowground. Mycorrhizal associations and fungal propagules usually suffer from degradative processes ${ }^{[51-53]}$. It has been clearly demonstrated that mycorrhizal activity, among other biological processes within the soil-plant system, is diminished by desertification in Mediterranean ecosystems ${ }^{[54]}$. Thus, spore densities were lower than in tropical ecosystems where mean spore densities were up to 476 per $100 \mathrm{~mL}$ soil ${ }^{[55]}$. The differences in spore density under and beyond shrub canopies are contradictory to the report of Carrillo-Garcia et $a l .{ }^{[19]}$ in which spore densities were higher in soils beneath shrubs than in interspatial positions. In other studies, shrub fertile islands contained the largest amounts of mycorrhizal inocula ${ }^{[18-20]}$. The explanation is that previous studies concentrated on the AM status of the shrubs themselves with absorbing roots deeply distributed within the soil. However, our study focused on herbaceous ephemerals with relatively shallow absorbing roots. The environments and shrub 
species were different in our study and in previous studies. Another possible explanation is that mycorrhizal inocula consist largely of hyphal fragments rather than spores, a conclusion that was drawn by Bashan et al. (2000) in their Sonoran Desert studies ${ }^{[56]}$.

Acknowledgements This work was supported by the National Natural Science Foundation of China (Grant No. 30470341) and Xinjiang Institute of Ecology and Geography, Chinese Academy of Sciences.

\section{References}

1 Garner W, Steinberger Y. A proposed mechanism for the formation of 'Fertile Islands' in the desert ecosystem. J Arid Environ, 1989, 16: $257-262$

2 Reynolds J F, Virginia R A, Cornelius J M. Resource island formation associated with the desert shrubs, creosote bush (Larrea tridentata) and mesquite (Prosopis glandulosa) and its role in the stability of desert ecosystems: A simulation model. Suppl Bull Ecol Soc Am, 1990, 70: 299-300

3 Schlesinger W H, Raikes J A, Hartley A E, et al. On the spatial pattern of soil nutrients in desert ecosystems. Ecology, 1996, 77: $364-374$

4 Callaway R M. Positive interactions among plants. Bot Rev, 1995, 61: $306-349$

5 Callaway R M. Positive interactions in plant communities and the individualistic-continuum concept. Oecologia, 1997, 112: 143149

6 Titus J H, Nowak R S, Smith S D. Soil resource heterogeneity in the Mojave Desert. J Arid Environ, 2002, 52: 269-292

7 Tiedemann A R, Klemmedson J O. Effect of mesquite trees on vegetation and soils in the desert grassland. J Range Manage, 1977, 30: $361-367$

8 McAuliffe J R. Markovian dynamics of simple and complex desert plant communities. Am Nat, 1988, 131: 459-490

9 Franco A C, Nobel P S. Effect of nurse plants on the microhabitat and growth of cacti. J Ecol, 1989, 77: 870-886

10 Valiente-Banuet A, Ezcurra E. Shade as a cause of the association between the cactus Neobuxbaumia tetetzo and the nurse plant $\mathrm{Mi}$ mosa luisana in the Tehuacan Valley, Mexico. J Ecol, 1991, 79: 961-971

11 He X L, Mouratov S, Steinberger Y. Temporal and spatial dynamics of vesicular-arbuscular mycorrhizal fungi under the canopy of Zygophyllum dumosum Boiss in the Negev Desert. J Arid Environ, 2002, 52: 379-387

12 Trappe J M. Phylogenetic and ecological aspects of mycotrophy in angiosperms from an evolutionary standpoint. In: Safir G R, ed. Ecophysiology of VA Mycorrhiza. Boca Raton: CRC Press, 1987. 5 $-25$

13 Wilcox H E. Mycorrhiza. In: Waisel Y, Eshel A, Kafkaki U, eds. Plant Roots: The Hidden Half. New York: Marcel Dekker, 1991. $731-765$
14 Schreiner R P, Mihara K L, McDaniell H, et al. Mycorrhizal fungi influence plant and soil functions and interactions. Plant Soil, 1997, 188: 199-209

15 Jeffries P, Barea J M. Arbuscular mycorrhiza-A key component of sustainable plant-soil ecosystems. In: Hock B, ed. The Mycota, IX Fungal Associations. Berlin: Springer-Verlag, 2001. 95-113

16 van der Heijden G A, Klironomus J N, Ursic M, et al. Mycorrhizal fungal diversity determines plant biodiversity, ecosystem variability and productivity. Nature, 1998, 396: 69-72

17 Requena N, Pérez-Solís E, Azcón-Aguilar C, et al. Management of indigenous plant-microbe symbioses aids restoration of desertified ecosystems. Appl Environ Microbiol, 2001, 67: 495-498

18 Bethlenfalvay G J, Dakessian S, Pacovsky R S. Mycorrhizae in a southern California desert, ecological implications. Can J Bot, 1984, 62: $519-524$

19 Carrillo-Garcia A, Leon de la Luz J L, Bashan Y, et al. Nurse plants, mycorrhizae, and plant establishment in a disturbed area of the Sonoran Desert. Restor Ecol, 1999, 7: 321-335

20 Dhillion S S. Environmental heterogeneity, animal disturbances, microsite characteristics, and seedling establishment in a Quercus havardii community. Restor Ecol, 1999, 7: 399-406

21 Azcón-Aguilar C, Palenzuela J, Roldán A, et al. Analysis of the mycorrhizal potential in the rhizosphere of representative plant species from desertification-threatened Mediterranean shrublands. Appl Soil Ecol, 2003, 22: 29-37

22 Ferrol N, Calvente R, Cano C, et al. Analysing arbuscular mycorrhizal fungal diversity in shrub-associated resource islands from a desertification threatened semiarid Mediterranean ecosystem. Appl Soil Ecol, 2004, 25: 123-133

23 Zhang L Y. The preliminary study on ephemerals in Mosowan District, Xinjiang. Acta Phytoecol Geobot Sin (in Chinese), 1985, 9(3): 213-221

24 Lapointe L. How phenology influences physiology in deciduous forest spring ephemerals. Physiol Plant, 2001, 113: 151-157

25 Zhang L Y. Ephemeral plants in Xinjiang (I): Eco-biological characteristics. Journal of Plant (in Chinese), 2002, 1:2-6

26 Wang X Q, Jiang J, Lei J Q, et al. The distribution of ephemeral vegetation on the longitudinal dune surface and its stabilization significance in the Gurbantunggut Desert. Acta Geog Sin (in Chinese), 2003, 58: 598-605

27 Guang G L, Li Z Y, Yang Y S, et al. Studies on the characteristics related to nitrogen fixation in the nodules of Trigonella arcuata in Xinjiang. Arid Zone Res (in Chinese), 1988, 5(4): 1-6

28 Li J, Akbar Y, Alimas K. An anatomical study on the vegetative organs of Senecio subdentatus Ldb. ephemeral plant in Xinjiang. Journal of Xinjiang Normal University (Natural Sciences Edition) (in Chinese), 2000, 19(4): 51-55

29 Wang Y. Phenological observation of the early spring ephemeral and ephemeroid plant in Xinjiang. Arid Zone Res (in Chinese), 1993, 10(3): 34-39

30 Yu X F, Liu A Q. A anatomical study on the ephmeral plant Lepidun Apalum Willd in Xinjiang. Journal of Xinjiang Normal University (Natural Sciences Edition) (in Chinese), 1997, 16(2): 34 $-38$ 


\section{ARTICLES}

31 Liu R J, Li X L. Arbuscular Mycorrhizas and Their Application (in Chinese). Beijing: Science Press, 2000. 66-68

32 Lu R K. Methods of Soil and Agricultural Chemistry Analyses (in Chinese). Beijing: China Agricultural Science and Technology Press, 1999. 1-227

33 Biermann B, Linderman R G. Quantifying vesicular arbuscular mycorrhizae: A proposed methods towards standardization. New Phytol, 1981, 87: 63-67

34 Trouvelot A, Kough J L, Gianinazzi-Pearson V. Mesure du taux de mycorhization VA d'un systeme radiculaire, recherche de methodes d'estimation ayant une signification funvtionnelle. In: Gianinazzi-Pearson V, Gianinazzi S, eds. Physiological and Genetic Aspectes of Mycorrhizae. Paris: INRA Press, 1986. 217-221

35 Sieverding E. Vesicular-arbuscular Mycorrhiza Management in Tropical Agrosystems. Eschborn: Deutsche Gesellschaft für Technische Zusammenarbeit, 1991. 367-371

36 Schenk N C, Perez Y. Manual for Identification of VA Mycorrhizal Fungi. Florida: Synergistic Publications, 1990. 1-255

37 Morton J B, Redecker D. Two new families of Glomales, Archaeosporaceae and Paraglomaceae, with two new genera Archaeospora and Paraglomus, based on concordant molecular and morphological characters. Mycologia, 2001, 93: 181-195

38 Zhao Y L, Zhao H L. A brief review on vegetation succession research in desertification processes of China. Journal of Desert Research (in Chinese), 2000, (Suppl): 7-14

39 Li X R, Zhang J G, Wang X P, et al. Study on soil microbiotic crust and its influences on sand-fixing vegetation in arid desert region. Acta Bot Sin, 2000, 42 (9): 965-970

40 Wang T, Zhu Z D. Some problems of desertification in northern China. Quaternary Science (in Chinese), 2001, 21(2): 56-65

41 Pawlowska T E, Taylor J W. Organization of genetic variation in individuals of arbuscular mycorrhizal fungi. Nature, 2004, 427: 733 $-737$

42 Francis R, Read D J. Direct transfer of carbon between plants connected by vesicular-arbuscular mycorrhizal mycelium. Nature, 1984, 307: 53-56

43 Lerat $\mathrm{S}$, Gauci R, Catford J G, et al. ${ }^{14} \mathrm{C}$ transfer between the spring ephemeral Erythronium americanum and sugar maple saplings via arbuscular mycorrhizal fungi in natural stands. Oecologia, 2002, 132: $181-187$
44 Smith S E, Read D J. Mycorrhizal Symbiosis. London: Academic Press, 1997. 1-378

45 Miller J C, Rajapakse S, Garber R K. Vesicular-arbuscular mycorrhizae in vegetable crops. Hortscience, 1986, 21: 974-984

46 Dhillion S S, Ampornpan L. The influence of inorganic nutrient fertilization on the growth, nutrient composition and vesicular-arbuscular mycorrhizal colonization of pretransplant rice (Oryza sativa L.) plants. Biol Fertil Soils, 1992, 13: 85-91

47 He X L, Mouratov S, Steinberger Y. Spatial distribution and colonization of arbuscular mycorrhizal fungi under the Canopies of desert halophytes. Arid Land Res Manag, 2002, 16: 149-160

48 Dhillion S S, Zak J C. Microbial dynamics in arid ecosystems: Desertification and the potential role of mycorrhizas. Rev Chil Hist Nat, 1993, 66: 253-270

49 Kennedy L J, Tiller R L, Jean C. Stutz associations between arbuscular mycorrhizal fungi and Sporobolus wrightii in riparian habitats in arid South-western North America. J Arid Environ, 2002, 50: $459-475$

50 Kennedy A C, Smith K L. Soil microbial diversity and the sustainability of agriculture soils. Plant Soil, 1995, 170: 75-86

51 Brundrett M C. Mycorrhizas in natural ecosystems. In: Macfayden A, Begon M, Fitter A H, eds. Advances in Ecological Research. London: Academic Press, 1991. 171-313

52 Jasper D A, Abbot L K, Robson A D. The effect of soil disturbance on vesicular-arbuscular mycorrhizal fungi in soils from different vegetation types. New Phytol, 1991, 118, 471-476

53 McLellan A J, Fitter A H, Law R. On decaying roots, mycorrhizal colonisation and the design of removal experiments. J Ecol, 1995, 83: $225-230$

54 Requena N, Jeffries P, Barea J M. Assessment of natural mycorrhizal potential in a desertified semiarid ecosystem. Appl Environ Microbiol, 1996, 62: 842-847

55 Zhao Z W, Xia Y M, Qin X Z, et al. Arbuscular mycorrhizal status of plants and the spore density of arbuscular mycorrhizal fungi in the tropical rain forest of Xishuangbanna, southwest China. Mycorrhiza, 2001, 11: 159-162

56 Bashan Y, Davis E A, Carrillo-Garcia A, et al. Assessment of VA mycorrhizal inoculum potential in relation to the establishment of cactus seedlings under mesquite nurse-trees in the Sonoran Desert. Appl Soil Ecol, 2000, 14: 165-175 